\author{
Guillem Castañar Rubio \\ University of Barcelona \\ ruchka80@yandex.ru
}

https://orcid.org/0000-0001-5969-0024

\title{
Multi-ethnic jokes in the Russian language
}

\begin{abstract}
The aim of this paper is to study variations and continuities in the targets of multi-ethnic jokes in the Russian language through time in three consecutive periods: Soviet era, post-socialist years and the present time. Multiethnic jokes are a subtype of ethnic canned jokes that feature two or more ethnonyms in one text, three being the most usual number of nationalities featured in the text and having, therefore, a tripartite structure. The different nationalities are placed in a special situation that usually entails some kind of competition between them. Our specific goals in this article are: 1) to analyse the position of the nationalities mentioned in the tripartite textual structure of the joke and their function within the text of the joke and to study structural variations through time; 2) to determine the ethnic scripts that are frequently ascribed to these targets and their changes from Soviet to present times; 3 ) to identify the nationalities that appear in multi-ethnic jokes in Russian and to detect changes in this cast of characters, if any, through the three chronological periods previously stated. The analysis of a corpus of 359 multi-ethnic jokes in the Russian language reveals that multi-ethnic jokes in Russian undergo few changes through times. Although they feature different nationalities in one text, multi-ethnic jokes in the Russian language are an example of reflexive ethnic humour, since they target Russians themselves.
\end{abstract}

Keywords: ethnic humour, multi-ethnic jokes, Russia

Ethnic humour is a term that cannot be easily defined. Many authors describe it as a broad and a complex phenomenon that generally relates to all kinds of humour targeting individuals or groups based on an ethnic otherness (Kuipers \& van der Endt, 2016: 4). Ethnic humour is often expressed by means of ethnic jokes, a special category of canned jokes that explicitly manifests differences between "us" and "others", a human tendency identified and studied by social psychologists (Turner, 1987). For a joke to be considered ethnic several conditions have to be met in our opinion: firstly, the joke has to be addressed to one or more target groups identified by the joke tellers as "others"; secondly, the "others" are always labelled with demonyms, ethnonyms or proper nouns. 
In this article, we study the evolution of targets of multi-ethnic jokes ${ }^{1}$ in the Russian language from the Soviet era to present times. These texts can be considered a subtype of ethnic joking, characterised by featuring more than one target from different nationalities in one text. Multi-ethnic jokes in the the Russian language from Soviet and post-socialist times have already been studied (Graham, 2003; Raskin, 1985; Shmeleva \& Shmelev, 2002), but we are not aware of any studies on contemporary targets of Russian multi-ethnic jokes, nor their evolution through time. We have conducted a diachronic study with multi-ethnic jokes in the Russian language from three different chronological periods: Soviet times (up to 1991), post-socialism (1991 to 1999) and current times (2000-2019). We are of the opinion that it is important to study this evolution, since these humorous texts are usually deemed as social facts closely linked to social reality (Davies, 2011) and, therefore, responsive to political, social or cultural changes. As Laineste and Fiadotava (2017: 85) assume, jokes change when there are changes in the political, social or cultural situation.

Our aims are: firstly, to identify the nationalities of the characters featured in Russian-language multi-ethnic jokes in these three periods and to detect any variations: whether some of these nationalities have disappeared from Russian-language multi-ethnic jokelore and whether new ones have turned up; secondly, to determine which position these nationalities occupy in the, as we shall see, frequently tripartite structure of the joke and their function within the text of the joke; thirdly, to describe how these nationalities are portrayed by pinning down the humorous scripts more often attached to them and to register any changes through time in this portrayal.

We start this study with an attempt to define multi-ethnic jokes. We consider these humorous texts to be a subtype of ethnic jokes. The reader will then find a brief theoretical framework including related concepts of script and ethnic reflexivity. However, Russian-language multi-ethnic jokes present some distinguishing features from other ethnic jokes in Russian - and from ethnic jokes in other languages - that will significantly inform the following section, devoted to the research questions posited in this work. We then move on to a description of the joke corpus collected for this study and how the data corpus has been chronologically divided. In this section, information is provided about the sources where the jokes were found. After that, we briefly describe the corpus and the analytical parameters. Finally, results are provided in detail, followed by conclusions.

\section{Multi-ethnic jokes: Definition}

Multi-ethnic jokes can be considered a subtype of ethnic joking. They are canned jokes containing a punchline, which display different ethnonyms in one joke text (Krikmann, 2012: 7). In these humorous texts, characters from different nationalities usually find themselves in an extraordinary situation. Frequent scenarios include an abduction by

1 There does not seem to be a terminological consensus when it comes to labelling these jokes: Raskin (1985) calls them "national superiority jokes", while Shmeleva \& Shmelev (2002) prefer the term "multi-national jokes". Graham (2003) chooses "multi-ethnic jokes", whereas "Three-nation jokes" is the choice of Krikmann (2012). Finally, Brzozowska (2013) goes for "jokes about three characters". We stick to "multi-ethnic jokes". 
aliens, a shipwreck on an uninhabited island or a plane crash without enough parachutes for everybody. Placed in an abnormal position, each of the characters of the multi-ethnic joke reacts differently, according to the conventional and fictional characteristics that joke tellers ascribe to the nationalities in the joke. The extraordinary situation is, in fact, a competition of sorts, and usually only one nationality wins. The number of characters from different nationalities featured in these jokes is variable: from two to as many as fifteen (Graham, 2003: 172), although most frequently the joke contains three different nationalities. Brzozowska highlights the "rule of three" (2013:23) as the basis of not only multi-ethnic jokes, but also of many folk texts found in different cultures (cf. Krikmann, 2012: 7).

Accordingly, these jokes have a tripartite structure and consist of three or more moves, as pointed out by Krikmann (2012: 15-16). Each of these moves performs a different function within the text of the joke: in the initial move, a first attempt is made to find a way out of the extraordinary situation in which the characters find themselves. In the middle move or moves, a second or more attempts are made. These additional moves are equally unsuccessful and semantically similar to each other. Therefore, they add nothing to the joke in a qualitative sense. The last (usually third) move generates a script change and a resolution in the form of a punchline. According to the position that they occupy in this three-piece set, Krikmann labels the characters as "initialisers", "follow-uppers", and "punch-line makers". Finally, as Raskin (1985: 202) observes, it must be noted that the character in the punch-line maker position and the teller of the joke frequently have the same nationality.

\section{Targets, scripts and other theoretical considerations in multi- ethnic joking}

We believe that the study of multi-ethnic jokes in the Russian language is better tackled if two theoretical considerations are taken into account. The first one is the concept of script, which we extract from the ground-breaking work on verbal humour done by Raskin (1985), who highlights that jokes in general and ethnic jokes in particular are constructed around conventional, fictional and mythological scripts (p. 180). Some of these scripts are purely ethnic, such as the scripts of dumbness, stinginess or cunning. However, ethnic humour uses more specific scripts as well. Some of them are rather universal, while others are specific, "always associated with a certain originating group, a certain targeted group, or both" (Raskin, 1985: 194). Thus, the script of an oversexed minority, which Russian ethnic jokes usually ascribe to Georgians, is a universal one, that can be found in the ethnic jokelore of many countries. However, Russian jokes targeting Armenians are based on a rather specific sexual script of paedophilia (Draitser, 1998: 166).

${ }^{2}$ Krikmann's terminology on structure and target position of characters will be used for analysis purposes in section 5 . 
Moreover, in his considerations about ethnic joking, Raskin introduces a clear distinction between ethnic and pseudo-ethnic jokes based mostly on scripts. He asserts that a joke about a group can be considered truly ethnic only if it is based on an accepted, conventional and already existing ethnic script on this group. Jokes that just mention a group but do not rely on a true ethnic script fall outside this category and must be labelled pseudo-ethnic jokes (Raskin, 1985: 207). The notion of script is a key element in this article, particularly concerning the analysis of the characterisation of each nationality in multi-ethnic jokes.

Concerning multi-ethnic joking, Raskin defines it as "anti-disparaging and self-glorifying", given these jokes aim to assert "the national superiority of the group, to which both the speaker and the hearer(s) belong, to all others" (p. 202). Graham highlights in the Russian variant of multi-ethnic joking the "consistent placement of the Russian himself (or herself) in the final 'humor-bearing' position" and the fact that these jokes exhibit a "penchant for satirical self-representation" traditionally present in folkloric Russian oral and written texts (2003: 173-174). He therefore considers multi-ethnic joking in Russian a case of "ethnic reflexivity".

The concepts of ethnic reflexivity and reflexive ethnic humour are in this study as important as the notion of script: the fact that multi-ethnic jokes are a type of reflexive ethnic humour has an effect on structure and structural changes in the joke, the quantity and quality of scripts attached to the nationalities featured in the joke, as well as on the selection of nationalities included in the joke.

\section{Research questions on contemporary Russian multi-ethnic jokes}

The research questions posited at the end of this section are informed by our own theoretical considerations exposed below.

As stated in section 1, we are not aware of any studies devoted to the contemporary targets of Russian multi-ethnic jokes, nor their chronological evolution. There are, though, some insights into Russian multi-ethnic jokelore from Soviet and post-socialist times in several works (Graham, 2003; Raskin, 1985; Shmeleva \& Shmelev, 2002). From these studies, it can be inferred that Russian multi-ethnic jokes from the two periods share some similarities regarding structures and scripts with their counterparts from other countries, particularly from former socialist states in Europe (cf. Krikmann, 2012; Brzozowska, 2013).

However, regarding target choice, Russian multi-ethnic jokelore shows some peculiarities. In Soviet and post-socialist multi-ethnic jokes, the Russian "hero" co-stars in the text with characters almost exclusively from Western countries, the most common being American, English, and French (Shmeleva \& Shmelev, 2002: 76), whereas in the same periods jokes from other Socialist countries such as Poland or Estonia combine targets from neighbouring countries and Westerners (see Brzozowska, 2013: 24; Krikmann, 2012: 12).

As has been noted in section 3, multi-ethnic jokes assert, according to Raskin, the national superiority of the ethnic group that "wins" in the joke (1985: 202), whose nationality coincides usually with that of the joke tellers and their audience. We believe these jokes 
to be reflexive ethnic humour (Graham, 2003: 157), since in these multi-ethnic jokes they become the butts of their own jokes. Multi-ethnic jokes in the Russian language target Russians, and targets are, quite often, victims. Although in multi-ethnic jokes there is a competition of sorts between nations and only one can win, it is also a fact that the winning nation - which is usually found in the punchline-maker position - is not always the best one, but the funniest or even the most stupid. In fact, and as noted by Shmeleva and Shmelev (2002: 75), in Russian multi-ethnic jokes the image of the Russian character who "wins" on most of the occasions - usually includes the negative features traditionally ascribed to Russians, such as alcoholism or stupidity.

We started this section asserting that multi-ethnic jokes from Soviet and post-socialist times share similarities. We should now consider what to expect from contemporary jokes. In some articles about jokes from former Socialist countries, it is stated that the demise of the USSR and the collapse of the Eastern Bloc brought significant changes to jokes, mainly related to the end of geographical isolationism and political censorship, as well as access to the Internet and the global community. In a study of three-nation Polish jokes, Brzozowska (2013: 25) notes that, thanks to Internet communication, jokes about three-characters in Poland can travel fast and easily reach a global audience. Moreover, jokes about local communities are now better-known by more people, and jokes about different nationalities have gained wider circulation. Laineste and Fiadotava (2017), in a survey looking at Estonian and Belarusian jokes from the 19th century to the most recent online jokes, describe the effects of globalisation on jokelore. They conclude that in contemporary Estonian and Belarusian ethnic joking locals are preferred to distant others as targets.

Bearing in mind the characteristics of multi-ethnic Russian joking in Soviet and post-socialist times (presence of Western nationalities and an inclination for ethnic reflexivity from Soviet times) and the significant changes that occurred in the Socialist bloc after the demise of the USSR, we undertake a diachronic comparative analysis of multi-ethnic Russian-language ethnic jokes to detect changes and continuities in this type of jokes through a time period that spans from Soviet to current times. The research questions posited are the following:

- What are the nationalities most frequently targeted in Russian-language multi-ethnic jokes throughout the different periods?

- What are the ethnic scripts more frequently ascribed to the butts in Soviet, post-socialist and current times?

- What position do targeted nationalities occupy in the tripartite structure of the multi-ethnic joke and what is their related function in the joke in the different periods studied?

\section{Data and methodology. Data corpus}

We have compiled a database of Russian multi-ethnic jokes found in printed and Internet sources for a period that spans from the first years of the Soviet Union to the year 2019 
$(\mathrm{N}=359)$. We have then divided the material into three sub-periods, listed below and followed by a brief account on terminological choices:

- Soviet period: early $20^{\text {th }}$ century $-1991(\mathrm{~N}=90)$.

- Post-socialism: $1992-1999(\mathrm{~N}=106)$.

- 21 $1^{\text {st }}$ century: $2000-2019(\mathrm{~N}=163)$.

\section{Joke sources}

Jokes for our data corpus have been found in printed and Internet sources. They range from the early twenties of the last century to present times. Below, the sources used for each sub-period can be found:

- Jokes from the Soviet period: found in the monograph by Raskin (1985), the PhD dissertation by Graham (2003), and the index of jokes' plots by Melnichenko (2014).

- Post-socialist jokes: jokes have been selected from the once popular website anekdot. ru and from monographs by Draitser (1998) and Shmeleva and Shmelev (2002).

- Jokes from the $21^{\text {st }}$ century: they come from different Internet sources. Amongst them, websites such as anekdot.ru and anekdotovstreet.ru, as well as joke groups in social networks Facebook and Vkontakte.

\section{Analysis parameters}

In order to answer the questions posited in section 3 , we have taken into account the following analysis parameters:

- appearance frequency of nationalities in Russian-language multi-ethnic jokes in each of the three periods;

- position of targeted nationalities in the tripartite structure of the joke in each of the three periods;

- ethnic scripts more frequently ascribed to the targeted nationalities in each of the three periods.

All the jokes have been classified according to these three parameters. Thus, for each joke we have looked for the nationalities mentioned in them, for the position that these nationalities hold in the joke and for the scripts associated with each of the nationalities. The results of the analysis of the data corpus are provided in the following section.

\section{Results}

Having explained the joke corpus, the sources and the parameters considered in the analysis of the data, in this section we present the findings with some accompanying comments and additional explanations. 


\section{Targets and nationalities}

One of the aims of this study is to determine which nationalities are most frequently targeted in multi-ethnic jokes in the Russian language. In order to attain this goal, we first identified all the nationalities that appear in the jokes in the three periods. Then, according to their appearance frequency, nationalities were ranked in descending order. In Table 1, a three-period ranking list is provided, including the ten most frequently targeted nationalities in Russian multi-ethnic jokes. Results show the share of ethnic targets on the total amount of jokes collected per each period.

Table 1. Share (\%) of ethnic targets in multi-ethnic Russian jokes

\begin{tabular}{|c|c|c|c|c|c|}
\hline \multicolumn{2}{|c|}{ SOVIET PERIOD } & \multicolumn{2}{c|}{ POST-SOCIALISM } & \multicolumn{2}{c|}{$21^{\text {st }}$ CENTURY } \\
\hline Russian & $95.5 \%$ & Russian & $82 \%$ & Russian & $87.7 \%$ \\
\hline French & $64 \%$ & American & $74 \%$ & German & $55.8 \%$ \\
\hline English & $52.2 \%$ & French & $64.1 \%$ & American & $50.9 \%$ \\
\hline American & $46.6 \%$ & English & $28.3 \%$ & French & $40.5 \%$ \\
\hline German & $21 \%$ & German & $16.9 \%$ & English & $21.5 \%$ \\
\hline Jewish & $18.8 \%$ & Jewish & $10.4 \%$ & Jewish & $12.8 \%$ \\
\hline Polish & $6 \%$ & Italian & $7.5 \%$ & Ukrainian & $10.4 \%$ \\
\hline Bulgarian & $5.5 \%$ & Ukrainian & $7.5 \%$ & Georgian & $6.1 \%$ \\
\hline Spanish & $5.5 \%$ & Japanese & $4.7 \%$ & Armenian & $6.1 \%$ \\
\hline Czech & $4.4 \%$ & Georgian & $3.7 \%$ & Italian & $5.5 \%$ \\
\hline
\end{tabular}

As has been stated in section 3, multi-ethnic jokes are considered in this study to be a case of reflexive ethnic humour. Thus, Russians are not surprisingly the most popular target in the three periods. Also for each of the periods, the most popular targets after the Russians are four Western nationalities, namely: American, English, French and German. In terms of target choice, multi-ethnic jokes do not follow the rules described by Davies in his theory of ethnic humour. The four most frequent nationalities targeted in these jokes are not neighbouring peoples and are not perceived amongst joke tellers as being backwards in terms of economic or cultural achievements. This is not only a characteristic of Russian multi-ethnic jokes, but a spread feature amongst jokes of this type in other countries. For instance, three-character Polish jokes chose Russians as favourite targets during Socialism, whereas in post-socialist times the preferred targets are EU nationalities as well as some Asian peoples, such as Japanese or Chinese (Brzozowska, 2013: 24-25).

Americans, English, French and Germans form, together with the Russians, a Group of Five, never outranked by other nationalities. However, the four Western nationalities combine differently with Russians in each period. Thus, multi-ethnic jokes in Soviet times most frequently feature a Russian, a Frenchman and an Englishman. The popularity of French and English targets decreases in the following periods and are replaced in the latest period by Americans and Germans. US representatives already win second place 
in post-socialist times. Targets from Germany become the second most popular target in these jokes in the $21^{\text {st }}$ century, followed by Americans. Therefore, the most common triad in the last period is made up of a Russian, a German and an American.

\title{
Targets and scripts
}

The second goal of our study is to identify ethnic scripts more frequently ascribed to the butts in Soviet, post-socialist and current times. This sub-section is organised by nationalities. For each of the nationalities included in the Group of Five, we describe the scripts that are usually attached to them, and their variations from one period to another period.

\section{Russians: from communism to alcoholism}

There is a considerable number of ethnic scripts attached to the Russian in all the periods studied. In multi-ethnic jokes from the post-socialist period, we have found up to twenty-six different scripts attached to the Russian character, whereas in the Soviet and current periods we have identified, respectively, a total of sixteen and twenty-one different scripts. Scripts linked to Russians are not only numerous, but also varied-aggressiveness, clumsiness, laziness - and even contradictory: some jokes are based on a script of sexual prowess whereas others are built on indifference to sex. However, in Soviet times, Russian characters in multi-ethnic jokes are rather frequently linked to scripts in which a political component can be found. Russians in these jokes are often presented as ideological fanatics who take any chance to spread the Soviet gospel, as can be observed in joke 1:

\begin{abstract}
Joke 1. An Englishman, a Frenchman and a Russian. The Russian is given instructions: "Whatever the conversation is about, you turn it around so that you can sing the praises of our system. Got it?". The Englishman starts boasting about his wife: "She rides a horse and her long legs touch the floor". The Frenchman boasts about his, too: "You can surround her waist with your fingers and the tips touch each other". The Russian: "When I leave home to go to work, I slap her on the ass. I go back and her ass is still trembling. Do you think she's got a special ass? We just have the shortest working day in the world". (Melnichenko, 2015: 1780)
\end{abstract}

In the same line, many of the Soviet jokes are set against a scenario darkened by the threat of repression or snitching by close relatives and friends, as well as problems caused by a deficit of basic products. In multi-ethnic jokes from Soviet times, political and ethnic borders are blurred. As Davies notes, in Socialist countries, where all aspects of life were politicised, so were the jokes (2015: 18). Nevertheless, in this period purely ethnic scripts can also be found, the most common one being the specific ethnic script of alcoholism. This script, outnumbered by various political scripts in Soviet times, becomes in the following two periods the most frequent one. In Shmeleva and Shmelev's words, "Russians in Russian jokes are drunkards, capable of anything for a drink" (2002: 75).

The upheaval of the early nineties in the Socialist bloc, which was accompanied by profound changes at many levels, had an impact also on jokes. In post-socialist times, 
as well as in the $21^{\text {st }}$ century, Russians in multi-ethnic jokes are linked mainly to ethnic rather than political scripts: the all-pervading script of alcoholism is the most frequent, although there are considerable numbers of jokes based on the universal ethnic scripts of cunning and stupidity, as in joke 2:

Joke 2. Three men are abducted by extra-terrestrials (a German, a Frenchman, and a Russian). They are locked in separate rooms, given two steel spheres each, and told that the one who does the most amazing thing with them will be released the following morning. Morning. The German is juggling the spheres. The Frenchman is juggling while singing and dancing. They decide to release the Frenchman (what else could be done with the spheres in a room without windows or doors?). Just to complete the experiment, they look in on the Russian. Five minutes later they go to the Frenchman and tell him that the Russian will be sent home. The Frenchman is in shock: "What did he do that I didn't do?" "He lost one sphere and broke the other!!" (Graham, 2003: 173)

\section{French and sex scripts}

Scripts attached to the French in Russian multi-ethnic jokes are limited to four or five in each of the periods. However, two of them are frequent and consistent through the three periods. The French are principally associated with scripts of an oversexed and promiscuous nationality. Raskin observes that, when associated with the French, the oversexed script is less universal, although the script is shared by many ethnic groups, i.e. "many ethnic groups maintain the myth about the French fixation on sex, their frivolity and blasé attitude to sex" (1985: 195). In other words, French people appearing in multi-ethnic Russian jokes are linked to sexual scripts that are widely used in many countries other than Russia. In Davies' words: “Jokes about the French - and especially French women - being oversexed and ignoring all the conventional rules of fidelity, propriety, and decency are common throughout Europe, North America and even further afield [...]. In the world's jokes, French men are seducers, rascals, and experts in sexual technique" (2011: 76). In joke 3, the French character is portrayed as oversexed:

Joke 3. Japanese scientists want to do some research on the reactions of people from different nationalities after the consumption of alcoholic drinks. They choose for the experiment a Frenchman, an American and a Russian. They attach electrodes to their bodies and switch on the computers. The Frenchman gets a glass of champagne. They look at the screen and a sexy girl appears. The American gets a tumbler with whiskey. The scientists look at the screen and see money, a car, a big house, etc. The Russian gets a shot of vodka, but nothing appears on the screen. Japanese scientists get him another shot. Two shots later, a tiny dot can be seen on the screen. Encouraged by the progress, the scientists decide to give the Russian three more shots. The small dot finally turns into a gherkin. (www.anekdot.ru, 1998) 


\section{Americans and money scripts}

On the one hand, Americans in multi-ethnic jokes resemble the French script-wise: not many scripts are attached to them, but they are consistently linked to money scripts - just as the French are related to sexual scripts - in the three periods: we have identified six different scripts for the first of the three periods and up to nine for post-socialist times. However, only money scripts appear in more than one joke. On the other hand, the scripts more frequently attached to Americans are rather specific. In Russian multi-ethnic jokes, US citizens are basically materialists. They firmly believe that problems can be solved with money and that every aspect of life can be turned into a business and, therefore, it becomes an opportunity for money to be made.

Joke 4. What threat is given by jealous wives to their husbands? In Spain: "I'll kill you!". In England: "I'll shame you!". In the USA: "I'll ruin you!". In the USSR: "I'll report you!". (Melnichenko, 2015: 1760)

Ethnic humour exploits, as we have stated in section 1, oppositions between "us" and "them". Thus, the association made in Russian jokes between money and Americans in jokes reflect, according to Tubalova (2008: 37), the confrontation between American materialism and a more ethical Russian world view inherited form Soviet times, by which money cannot buy happiness and there are no honest ways to become rich. Thanks to the multi-character format of these jokes, such antagonism can be made explicit in just one text.

\section{English, Germans and sundry scripts}

In multi-ethnic Russian jokes the English are associated with non-universal specific ethnic scripts such as cold politeness, shyness or awareness of social position, used by many ethnic groups when telling jokes about the English (Raskin, 1985: 197). However, there are several scripts attached to the English with equally low frequency, making it difficult to get a clear picture of how the English are depicted in multi-ethnic jokes. For instance, we have identified up to fifteen different scripts in Soviet times and the three most frequent of them - materialism, awareness of social position and love of sport - appear only in $20 \%$ of the jokes. Most of the scripts appear in only $6 \%$ of the jokes. Scripts change in each period. Characterisation of Germans in multi-ethnic Russian jokelore is, on the one hand, similar to that of the English: Germans are mainly associated with non-universal specific scripts such as prudency, methodicalness and love of beer. However, it is an even blurrier situation: the most frequent script in each period is different and its appearance frequency, equally low. On many occasions, English and German characters appear in these jokes without any distinguishing feature. Only the ethnonym is mentioned and is included in the joke to meet the demands of its tripartite structure. This loose characterisation might account for changes between the two first positions, i.e. from "initialiser" to "follow-upper" or vice versa, as happens with the Germans. Similarly, in her study of three-character Polish jokes, Brzozowska detects that Germans, who are "rarely strongly characterised" and are not targets in the 
jokes, also appear frequently the middle position (2013: 24). There are many jokes with German or English characters, similar to joke 5:

Joke 5. World Swearing Championship. An Englishman, a German, an American and a Russian have made it to the final. It is time for them to perform. The Englishman goes first. He swears for an hour. Then goes the German. He swears for one and a half hours. Then goes the American. He swears for two hours! It is the Russian's turn. He enters the hall, approaches the judges, his foot catches in the rug and he stumbles. After that, he swears for five hours. Then, once appeased, he goes to the judges and asks them: "So what? Can I start?" (www.anekdotovstreet.com, 2015-2018)

\section{Targets and position}

The third goal of the study is to find out the position that the most frequently targeted nationalities - the Group of Five - usually occupy in the tripartite structure of the joke for each studied period. As stated in section 2, multi-ethnic jokes usually have three parts, each of which features a different nationality described as "initialiser", "follower" or "punchline-maker" according to the position held in the joke. We have checked and counted the position that American, English, French, German and Russian targets occupy in the jokes selected. We have then calculated the share (\%) of each nationality in every position over the total amount of jokes featuring these nationalities, for each period. Results are shown in Tables 2-4.

Table 2. Share (\%) of positions held by ethnic characters in jokes from the Soviet period

\begin{tabular}{|l|l|l|l|}
\hline & \multicolumn{1}{|c|}{ INITIALISERS } & \multicolumn{1}{|c|}{ FOLLOW-UPPERS } & PUNCHLINE-MAKERS \\
\hline Russian & $5,95 \%$ & $17.86 \%$ & $\mathbf{7 6 . 1 9 \%}$ \\
\hline French & $22.03 \%$ & $\mathbf{7 6 . 2 7 \%}$ & $1.69 \%$ \\
\hline English & $\mathbf{6 8 . 8 9 \%}$ & $28.89 \%$ & $2.22 \%$ \\
\hline American & $\mathbf{5 0 \%}$ & $38.89 \%$ & $11.11 \%$ \\
\hline German & $\mathbf{5 7 . 1 4 \%}$ & $42.86 \%$ & \\
\hline
\end{tabular}

Table 3. Share (\%) of positions held by ethnic characters in jokes from the Post-socialist period

\begin{tabular}{|l|l|l|l|}
\hline & \multicolumn{1}{|c|}{ INITIALISERS } & \multicolumn{1}{|c|}{ FOLLOW-UPPERS } & PUNCHLINE-MAKERS \\
\hline Russian & $2,22 \%$ & $16.67 \%$ & $\mathbf{8 1 . 1 1 \%}$ \\
\hline French & $23.81 \%$ & $\mathbf{7 3 . 0 2 \%}$ & $4.76 \%$ \\
\hline English & $\mathbf{5 8 . 8 2 \%}$ & $38.24 \%$ & $38.24 \%$ \\
\hline American & $\mathbf{6 5 . 3 8 \%}$ & $32.05 \%$ & $2.56 \%$ \\
\hline German & $35.29 \%$ & $\mathbf{6 4 . 7 1 \%}$ & \\
\hline
\end{tabular}


Table 4. Share (\%) of positions held by ethnic characters in jokes from current times

\begin{tabular}{|l|l|l|l|}
\hline & \multicolumn{1}{|c|}{ INITIALISERS } & \multicolumn{1}{|c|}{ FOLLOW-UPPERS } & PUNCHLINE-MAKERS \\
\hline Russian & $7.19 \%$ & $11.51 \%$ & $\mathbf{8 1 . 2 9 \%}$ \\
\hline French & $33.3 \%$ & $\mathbf{6 5 . 0 8 \%}$ & $1.59 \%$ \\
\hline English & $\mathbf{5 5 . 5 6 \%}$ & $44.44 \%$ & \\
\hline American & $\mathbf{6 2 . 5 \%}$ & $33.75 \%$ & $3.75 \%$ \\
\hline German & $44.55 \%$ & $\mathbf{5 4 . 4 6 \%}$ & $0.99 \%$ \\
\hline
\end{tabular}

Again, it does not come as a surprise that Russians occupy eminently the position of "punchline-makers" in all three periods. Multi-ethnic jokes are reflexive ethnic jokes. Therefore, Russians are not only the most frequently mentioned nationality in these jokes, but they also constitute the source of the humorous effect of these texts and, accordingly, they hold the humour-bearer position.

As for the other nationalities included in the Group of Five, English, French and Americans do not change positions in the structure of these jokes throughout the three periods: French are usually "follow-uppers" and both English and Americans stick to the position of "initialisers". Again, there is only one noticeable change through times, and it is again related to the German character: in the Soviet period, Germans are mainly "initialisers", whereas in the following periods they shift to the middle position.

\section{Conclusion}

In this article, we have tried to determine the changes that time has brought to multi-ethnic jokes in the Russian language in terms of structure, scripts and target choice.

Concerning the structure of these jokes, few changes can be observed: most of the targeted nationalities hold the same position in the tripartite structure of multi-ethnic Russian jokes through the three chosen periods of study. English and American nationalities act primarily as "initialisers". French are mostly "follow-uppers", whereas Russians are usually "punchline-makers". Multi-ethnic jokes in the Russian language are reflexive ethnic humorous texts and, therefore, it does not come as a surprise that the Russians hold exclusively the humour-bearer position in the jokes and the other nationalities do not. Even if other nationalities change positions - as happens with the German character, who shifts from being an "initialiser" in Soviet times to a "follow-upper" in the subsequent periods -, they never become "punchline-makers".

As far as scripts are concerned, it must be observed first that Russians are portrayed in greater detail than the other nationalities. The number of scripts attached to them is larger, too. Again, it is hardly surprising, since these multi-ethnic jokes in Russian target Russians first and foremost. In the Soviet period, there is a notable presence of political scripts, although with the demise of the USSR they disappear and Russians are portrayed mainly by means of purely ethnic scripts: one of them, alcoholism, is a specific ethnic script, whereas the other two are universal: stupidity and. These scripts are the most common ones attached to Russians both in post-socialist and current times. French and Americans 
are characterised through the three periods by the consistent use of one or two specific scripts: frivolity and promiscuity for the former; materialism and money-related scripts for the latter. In contrast, English and Germans are characterised loosely, if at all. In each of the periods, different non-universal scripts, used by many groups of joke tellers, are attached to them. However, the use of these scripts is not consistent and their appearance frequency is low. In fact, in many jokes featuring English and Germans scripts are not attached and only the ethnonym is mentioned. We believe that this lack of characterisation might account for the previously observed change in the position of Germans in the structure of the joke: the German character is vague enough to be placed anywhere except in the "punchline-making" position, since this nationality is not the targeted one.

Regarding the nationalities that appear in the jokes, Russians are the favourite nationality in these jokes throughout all three periods. It is also the targeted nationality in the joke: on most occasions - in Soviet and post-socialist times, as well as in the $21^{\text {st }}$ century - they appear last in the joke, holding the "punchline-maker" position, that is, the humour-bearing position. The other nationalities are just added players. It can be reasonably stated, therefore, that these texts were and still are a clear example of ethnic reflexivity as stated by Graham (2003: 157): Russians hold the humour-bearing position, are the most frequently mentioned nationality in the jokes.

However, it must be highlighted that Russians appear in the jokes with four more Western nationalities picked from a very short list: Americans, English, French and Germans. Reasons can be found to account for this particular choice of targets. Americans, for instance, become a significant "other" for the Russians in the $20^{\text {th }}$ century. According to Tubalova (2008: 37), the appearance of Americans in Soviet jokes is the result of the widespread propaganda myth of the American military threat and the cultivated axiological opposition USSR/USA during Soviet times. Thus, the presence of Americans in these jokes can be related to the politicization of all aspects of Soviet life, which was especially intense in the early stages of Bolshevik power (Melnichenko, 2015: 11) and was maintained throughout the entire Soviet period. The pervasiveness of politics provoked a politicization of humour and, in the case of jokes, blurred the lines between political and other kinds of jokes. As Davies aptly states, where absolutely everything is related to politics, so are the jokes (2015: 18). According to Tubalova, this confrontation did not cease with the end of the Cold War: 'at present, the well-established opposition 'Russia/America' is still a current topic in jokes, maintained by social stereotypes that define the American, in relation to Russians, as a symbol of the 'outsider', the 'other', the 'ethno-cultural opponent', the one who is "worse than Russians"' (2008: 37).

Concerning the Germans, they have an even longer tradition in Russian history as a Significant Other, still existing nowadays. According to Barash (2012: 93-94), until the mid-19 $9^{\text {th }}$ century, the image of the German in Russia was mainly positive. Features attached to Germans in Russian literature of that time were thriftiness and accuracy. For quite a long time, starting at Petrine times, Germans were seen as carriers of progress, and the very name of Germany was associated with universities. However, after the Unification of Germany in 1871, Russians started to perceive the new country as a threat. Germans become soldiers and enemies, an image that was reinforced during World War I and, 
especially and for obvious reasons, during World War II. The division of Germany had a positive effect on the image of Germans in Russia, since it was perceived that part of the country was sharing a common destiny with the USSR and, gradually, the perception of Germans lost its conflictive qualities.

Historical reasons can likely explain the presence of the other two targeted nationalities, French and English, in these jokes in terms of significant otherness. However, we believe that all these nationalities are chosen because they are powerful and developed Western nations that might be deemed superior by Russians, but not in the symbolic space of the joke, where they are funnily, unexpectedly and ridiculously "vanquished" by Russians' weaknesses. As Tubalova observes when writing on the role of Americans in Soviet jokes, these texts allowed a carnival-like reversal of reality, by which the petty domestic human flaws of the Russians turned into superiority over the Americans (2008: 37). The same applies to the other nationalities in multi-ethnic jokes. Victorious Russians in these jokes are not better than their competitors; their "human flaws" are always present, highlighted even, when they win or overcome a situation. Multi-ethnic joking in the Russian language is more about Russians themselves than about the others.

\section{References}

Barash R.E. (2012), Figura “Drugogo” kak Znachimaya Sostavlyayushchaya Rossiyskoy/ Russkoy Identichnosti [The "Other" as a significant component of Russian Identity], "Monitoring Obshchestnogo Mnyeniya”, nr 1 (January-February), 90-99.

Brzozowska D. (2013), Three Characters in Polish Jokes [in:] ESTONIA AND POLAND: Creativity and Tradition in Cultural Communication, 21-32. https://doi.org/10.7592/ep.1.brzozowska

Davies C. (2011), Jokes and Targets, Indiana University Press, Bloomington.

Draitser E. (1998), Taking Penguins to the Movies: Ethnic Humor in Russia, Wayne State University Press, Detroit.

Graham S. (2003), A Cultural Analysis of the Russo-Soviet Anekdot (doctoral dissertation). Retrieved from http://d-scholarship.pitt.edu/9560/1/grahamsethb etd2003.pdf

Krikmann A. (2013), Estonian Three Nation Jokes (1964-2012) [in:] ESTONIA AND POLAND: Creativity and Tradition in Cultural Communication, 7-20. https://doi.org/10.7592/ ep.1.krikmann

Kuipers G., van der Ent B. (2016), The Seriousness of Ethnic Jokes: Ethnic Humor and Social Change in the Netherlands, 1995-2012, "Humor", 29(4). https://doi.org/10.1515/ humor-2016-0013

Laineste L., Fiadotava A. (2017), Globalisation and Ethnic Jokes: A New Look on an Old Tradition in Belarus and Estonia, "The European Journal of Humour Research", 5(4), 85-111. https://doi.org/10.7592/ejhr2017.5.4.laineste

Melnichenko M. (2015), Sovetskiy Anekdot (Ukazatel Syuzhetov) [The Soviet Joke (Plots Classification)], Novoye Literaturnoye Obozreniye, Moscow.

Raskin V. (1985), Semantic Mechanisms of Humor, D. Reidel Publishing Company, Dordrecht. 
Shmeleva E.Y., Shmelev A.D. (2002), Russkiy Anekdot. Tekst i Rechevoy Zhanr [The Russian Joke. Text and Speech Genre], Yazyki Slavyanskoy Kultury, Moscow.

Tubalova I.V. (2008), “Golosa” Sovetskoy Epokhi v Polifonicheskoy Strukture Sovremennogo Anekdota [The "Voice" of the Soviet Period in the Polyphonic Structure of the Contemporary Joke], Vestnik Tomskogo Gosudarstvennogo Universiteta, 313, 34-38.

Turner J.C., Reynolds K.J. (1987), Self-Categorization Theory. Handbook of Theories of Social Psychology, 399-417; https://doi.org/10.4135/9781446249222.n46

\section{Streszczenie}

\section{Multietniczne anegdoty w języku rosyjskim}

Celem artykułu jest zbadanie zmian oraz sukcesji obiektów multietnicznych anegdot $w$ języku rosyjskim w trzech następujących po sobie okresach: epoki radzieckiej, postsocjalizmu oraz współczesności. Wielonarodowe anegdoty to rodzaj anegdot etnicznych, w których w jednym tekście przedstawione są co najmniej dwa etnonimy. Zazwyczaj w jednej anegdocie figurują trzy narodowości, a zatem można stwierdzić, że anegdoty te posiadają trójstronną strukturę.

W anegdocie przedstawiciele różnych narodowości znajdują się w szczególnej sytuacji, która zwykle powoduje jakąś rywalizację między nimi. Konkretne zadania postawione w artykule to: 1) analiza funkcji oraz statusu narodowości wspomnianych $\mathrm{w}$ anegdocie $\mathrm{w}$ trójstronnej strukturze tekstowej anegdoty w ciągu czasowym; określenie skryptów etnicznych, które są często przypisywane tym obiektom, i ich zmiany, począwszy od czasów radzieckich po dzień dzisiejszy; 3) określenie narodowości, które pojawiają się w wieloetnicznych anegdotach w języku rosyjskim i ukazanie zmian w tym zbiorze postaci w ciągu trzech okresów chronologicznych. Analiza korpusu 359 multietnicznych anegdot w języku rosyjskim pokazuje, że anegdoty te nie ulegają większym zmianom na przestrzeni kilkudziesięciu lat. Mimo że w jednym tekście przedstawione są trzy narodowości, multietniczne anegdoty w języku rosyjskim są przykładem refleksyjnego humoru etnicznego, ponieważ są one nakierowane na samych Rosjan.

Slowa kluczowe: humor narodowy, multietniczne anegdoty, Rosja 